\title{
Symbolika klasztornego wirydarza
}

\begin{abstract}
The garden is connected with Man from thousands of years. However the question is - what garden means for people? One of its very important meaning is „paradise regained”. This name is applied for cloister garth (in Polish „wirydarz”), extraordinary garden, entirely permeated by symbolism. The comprehensive symbolism of this special place, in particular concerning its shape (usually square or circle), components (walls, gates, galleries) and composition of cultivated plants are described and shortly commented.
\end{abstract}

Key words: cloister, garth, garden, paradise, symbolism, wirydarz.

\section{Wirydarz jako rajski ogród}

Wirydarz, określenie, które nieodparcie kojarzy się z ogrodem zarówno w języku potocznym, jak też w kontekstach symbolicznych, współcześnie wydaje się już nieco staroświeckie. Niemniej wciąż jeszcze żyje i pozostaje w użyciu, mimo że obecnie raczej dość rzadko tworzy się nowe tego typu założenia ogrodowe. 
Ponieważ z ogrodami w różnej formie mamy do czynienia od bardzo dawna, warto postawić sobie pytanie - czym one są dla człowieka:

- czy wyrazem podporządkowania i ukształtowania przyrody zgodnie z naszymi pragnieniami;

- czy zastępują naturę, gdyż tworząc ogrody, próbujemy poprawić sobie samopoczucie, wprowadzając w nasze otoczenie namiastkę prawdziwej przyrody;

- czy są dziełem sztuki, kiedy formujemy ich kształt;

- czy rajem odzyskanym lub - lepiej powiedzieć - odzyskiwanym, jako że człowiek pragnie posiąść na powrót to, co niegdyś utracił?

Przeglądając mniej lub bardziej zawiłe definicje dotyczące określenia "ogród”, z pewnością zauważymy, że są w nich uwypuklone dwie zasadnicze, łączące je cechy, a mianowicie - wydzielenie lub oddzielenie oraz zagospodarowanie czyli specjalne, celowe uprawianie. Ogród jest zatem miejscem zespolenia form naturalnych z kulturowymi. W słowie wstępnym do katalogu wystawy pt. „Ogród. Forma - Symbol - Marzenie” z roku 1998 czytamy: „Ogród to fenomen powstający na skrzyżowaniu sztuki, literatury, wątków filozoficznych i religijnych, a także mód i codziennych obyczajów". Inaczej mówiąc, w ogrodzie zharmonizowane są trzy aspekty: przyrodniczy (środowiskowy), społeczny (wspólnotowy) i religijny (duchowy) ${ }^{1}$.

Symbolika ogrodu jest bardzo bogata. Uosabia on m.in.: szczęście, odkupienie, czystość, dziewictwo, dom, schronienie, odpoczynek, piękno, urodzaj, wiosnę, wesołość, radość, tajemnice duszy, zbawienie, modlitwę, odosobnienie i medytację. Ponadto - otoczony murem, w którym jest tylko wąska brama, sugeruje trudności, przeszkody, konieczne do pokonania przy osiąganiu wyższego stopnia rozwoju psychicznego, zaś otoczony żywopłotem symbolizuje, z męskiego punktu widzenia, intymne części ciała kobiecego. Ma być też np. symbolem okiełznania

1 B. Zemanek, Ogród - raj odzyskany czy substytut natury [w:] Ogród Pana. XVIII Międzynarodowe Seminarium Sacrum i Przyroda, red. J. Brusiło, Kraków 2010, s. 27-28. 
natury przez przyrodę, jak też władzy rozumu nad impulsami podświadomości².

Jednak symbolem ogrodu, który nas najbardziej interesuje, to symbol Raju, a za symbol raju na ziemi uznawane były - i zapewne są do tej pory - wirydarze klasztorne.

Według Księgi Rodzaju świat istnieje wyłącznie dzięki wolnej woli Boga, co pięknie wyraziła, żyjąca w XI w., św. Hildegarda z Bingen: „Odwieczna mocy,/ w Twym sercu/ nadałaś światu kształt/ i powstał on na jedno Twoje Słowo,/ tak, jak chciałeś”’. O wiele wcześniej, bo w Księdze Syracha możemy przeczytać: „On ustanowił w pięknym porządku wielkie dzieła swej mądrości (...) Jakże godne ukochania są wszystkie Jego dzieła (...) i nie mają żadnego braku” (Syr 42, 21-24)4.

Bez wątpienia wyrazem mocy Bożej było stworzenie ogrodu rajskiego. Opis tego zdarzenia znajdziemy w Księdze Rodzaju ${ }^{5}$. Raj był zatem symbolem hojności Boga, ładu kosmicznego, bezgrzesznego bytu ludzkości, poczucia szczęścia naszych prarodziców, wreszcie - symbolem ich bliskości i przyjaźni z Bogiem. Wszystko to jednak dotyczy stanu przed okazaniem Stwórcy nieposłuszeństwa.

Wiemy, że Bóg powierzając człowiekowi pieczę nad ogrodem, jednocześnie zakreślił wyraźnie uprawnienia i kompetencje opiekuna.

2 W. Kopaliński, Słownik symboli, Warszawa 2006, s. 269; Leksykon symboli - Herder, przeł. J. Prokopiuk, Warszawa 2009, s. 200; Symbole i alegorie. Leksykon - historia, sztuka, ikonografia, Warszawa 2011, s. 252.

3 Modlitwy Hildegardy z Bingen, oprac. W. Storch, tłum. K. Wiwer, Kraków 2008, s. 30 .

4 Cytaty pochodzą z: Pismo Święte Starego i Nowego Testamentu. Biblia Tysiąclecia, Wyd. Iv, Poznań 1991.

5 „A zasadziwszy ogród w Edenie na wschodzie, Pan Bóg umieścił tam człowieka, którego ulepił./ Na rozkaz Pana Boga wyrosły z gleby wszelkie drzewa miłe z wyglądu i smaczny owoc rodzące oraz drzewo życia w środku tego ogrodu i drzewo poznania dobra i zła./ ... Pan Bóg wziął zatem człowieka i umieścił go w ogrodzie Eden, aby uprawiał go i doglądał./ A przy tym Pan Bóg dał człowiekowi taki rozkaz: $Z$ wszelkiego drzewa tego ogrodu możesz spożywać według upodobania;/ ale z drzewa poznania dobra i zła nie wolno ci jeść, bo gdy z niego spożyjesz, niechybnie umrzesz ( $\operatorname{Rdz} 2,8-9,15-17)$. 
Spod ludzkiej jurysdykcji było wyłączone jedynie drzewo poznania dobra i zła, z którego nie wolno mu było zrywać owoców. Wiemy też, że człowiek okazał się istotą słabą, podatną na szatańskie podszepty. Popełnił grzech zwany pierworodnym, zrywając zakazany owoc. Jak napisał w jednym z wierszy Juliusz Słowacki: „Z wami trzeci ja, wąż./ Jeśli masz ognia mało,/ To ściągnij oto dłoni/ Po owoc tej jabłoni,/ Jej duchem podkarm ciało,/ Ty będziesz świata panią!.../ Lecz już z jabłkiem od drzewa/ Biegła w płomieniach Ewa./ A szatan poszedł za nią." Wtedy skończyła się rajska sielanka we dwoje, słodkie teté á teté. Człowiek został z Raju wypędzony. W ten sposób utracił nie tylko swą niewinność, ale i prawidłową więź z otaczającym środowiskiem, tak początkowo dla niego przyjaznym. W Raju człowiek nie żył bez sensu. Miał uprawiać ogród, jako kontynuator dzieła Bożego. Praca nie była ciężkim obowiązkiem, ale powołaniem, „nie była utrapieniem” lecz - jak chce św. Augustyn - „źródłem rozkoszy” (non laboriosa, sed deliciosa). Co więcej, jak pisał John Milton w „Raju utraconym” praca była "godłem jego [człowieka] dostojeństwa”. W nowej sytuacji, po wypędzeniu z Raju, człowiek musiał wydzierać z zasobów przyrody to, co było mu konieczne do życia.

Wyniesioną tęsknotę za Rajem wygnana para przekazała swemu potomstwu! Nic zatem dziwnego, że człowiek pragnąc powrócić do utraconego Raju, do Edenu, starał się zrobić wszystko, aby tworzyć tu, na ziemi przestrzenie, czyli ogrody-wirydarze, które by mu Eden przypominały!

Rdzeń słowa „eden” występuje w językach hebrajskim, arabskim i syryjskim. Edin po sumeryjsku oznacza „równinę”. W mitologii sumeryjskiej spotykamy się z prototypem Raju, krainą (wyspą) Dilmun, lokowaną w dzisiejszym Bahrajnie nad Zatoką Perską. To kraj bez chorób, zmęczenia, starości i śmierci, czysty i lśniący. I chociaż raj

6 J. Słowacki, Dzieła t. 1: Liryki i inne wiersze, red. J. Krzyżanowskiego. wyd. III, Łódź 1959, s. 182.

7 J. Delumeau, Historia raju. Ogród rozkoszy, Warszawa 1996, s. 182, 187. 
sumeryjski i biblijny różnią się od siebie, gdyż powstały na podstawie zupełnie innych przesłanek, wizja sumeryjska musiała być mocno sugestywna, skoro przetrwała tysiące lat i oddziaływała na wyobraźnię autorów Księgi Rodzaju8.

W języku hebrajskim wyraz ten można odczytać jako „rozkosz” i dlatego w Księdze Rodzaju (rozdział 2) ogród Eden to „ogród rozkoszy".

Biblie Septuaginta, a potem Vulgata ogród taki nazywały rajem (łac. Paradisus), nawiązując do perskiego określenia „pairidaeza”, co znaczy miejsce zamknięte, ogrodzone, jakim zresztą były perskie ogrody królewskie („pairi” - dookoła, „daeza” - mur). O takim ogrodzie, paradeisos, pisze Ksenofont z Aten (ok. 430-335 przed Chr.), w dziele złożonym z siedmiu ksiąg, pt. „Wyprawa Cyrusa” (gr. Anábasis) ${ }^{9}$.

\section{Początki klasztornych wirydarzy}

Słowo wirydarz wywodzi się od łacińskiego viridis - „zielony”, „zielonawy", a więc porośnięty zieloną roślinnością.

Wirydarze zaczęły powstawać po vi w., kiedy po upadku cesarstwa rzymskiego zaczęła podupadać także sztuka ogrodowa. Jej pozostałości ocalały właśnie w klasztorach. Kiedy na przełomie viı i Ix w. zaczęła się tworzyć nowa potęga państwowa, cesarstwo Karola Wielkiego, porzymskie posiadłości wiejskie, zaczęli zajmować mnisi, wzorując się na ogólnym schemacie ich zabudowy - dziedziniec czyli wirydarz (u Rzymian - perystyl) otoczony czterema krużgankami. Przyjmuje się, że pierwszym klasztorem opartym na takim schemacie był klasztor w Lorsch (środkowa Nadrenia), zbudowany w viı w. Tradycja zakonna kazała zakładać ogrody głównie w celach utylitarnych, dla uprawiania warzyw, ziół i owoców.

8 T. Jelonek, O raju i złotym wieku, Kraków 2010, s. 11.

9 P. Hobhouse, Historia ogrodów, Warszawa 2005, s. 19. 
Pewnie dlatego prekursorami sztuki ogrodowej byli benedyktyni, ponieważ reguła św. Benedykta z Nursji (vi w.) zawierała zasadę samowystarczalności zakonu, a za swą dewizę uważali stabilitas loci, a więc stałość miejsca. Nieco później św. Izydor z Sewilli sformułował regułę, również zawierającą zalecenia dotyczące uprawy ogrodów klasztornych.

Nieco odmienne podejście do zakładania ogrodów klasztornych miały zakony żebrzące, dominikanie i franciszkanie, żyjący przeważnie w miastach. Niemniej i oni część terenów przyklasztornych wydzielali jako założenie ogrodowe. Mówi o tym np. „Księga o górze najświętszej modlitwy” (xIV w.), w której znajduje się opis mistyczny ogrodu w kształcie kwadratu, otoczonego murem z siedmioma wieżami, symbolami darów Ducha Świętego, z ogromną bramą, symbolizującą sumienie, a strzeżoną przez psa, uosobienie rozumu. Sam św. Franciszek zalecał pozostawiać w klasztorach „nieuprawne obrzeże, aby na nim w swoich porach zieleń ziół i piękno kwiatów głosiły Ojca wszystkich pięknych rzeczy”. Jest to równocześnie myśl dotycząca ochrony przyrody nie z uwagi na jej wartości użytkowe, ale ze względu na wartość przyrody samej w sobie ${ }^{10}$.

\section{Elementy architektoniczne wirydarza - ich symbolika}

Religijność średniowiecza obejmowała właściwie wszystkie dziedziny życia. Johan Huizinga (1872-1945), holenderski historyk, eseista i językoznawca, autor dzieła „Jesień średniowiecza”, pisał: „Życie średniowiecznego świata chrześcijańskiego we wszystkich swoich związkach przeniknięte jest, ba, nawet przesycone wyobrażeniami religijnymi. Nie ma takiej sprawy ani takiej akcji, która nie pozostawałaby w stałym

10 S. Kobielus, Człowiek i ogród rajski w kulturze religijnej średniowiecza, Warszawa, 1997, s. 139-140; M. Krenz, Średniowieczna symbolika wirydarzy klasztornych, Kraków 2005, s. 97-101; S. Jaromi, Idea ogrodu św. Franciszka jako przykład chrześcijańskiej troski o bioróżnorodność, [w:] Ogród Pana. XVIII Międzynarodowe Seminarium Sacrum i Przyroda, red. J. Brusiło, Kraków 2010, s. 83-94. 
związku z Chrystusem i wiarą" ${ }^{11}$. Duch tej pobożności był mocno przesycony oczekiwaniem sądu bezpośrednio po śmierci lub Sądu Ostatecznego. Dlatego, chociaż z jednej strony ludzie obawiali się Boga jako surowego sędziego, to z drugiej strony wierzyli, że odwrócenie się od grzechu i pokuta doprowadzą ostatecznie do obiecanego raju. Jego wyobrażenia były różne. $\mathrm{W}$ potocznym mniemaniu owym rajskim ogrodem czyli Niebieskim Jeruzalem było niebo, ale przesycone zmysłowością i materialnością, ponieważ spodziewano się, że właśnie tam ludzie dostaną w nadmiarze wszystko to, czego im zbywało na ziemi. Natomiast według teologów i mistyków w niebie mamy oglądać Boga i - co chyba najważniejsze - w pełni zjednoczyć się z Nim w miłości ${ }^{12}$.

Wstępne zjednoczenie z Bogiem mogło nastąpić już tu, na ziemi, a pomocne w tym miały być wirydarze, symbole utraconego Raju. Samo życie zakonne to swoisty powrót do Raju, a nawet antycypacja w rajskich dobrach. Wirydarz sprzyja duchowemu wyciszeniu, medytacji i modlitwie, w efekcie - zbliżeniu do Boga, aby z Nim porozmawiać, czyli dostąpić przywileju jaki przecież mieli przed upadkiem nasi prarodzice. Tak więc życie mnichów, „zbiegów ze świata” (fuga mundi), było powrotem do „stanu Adama”.

Zapewne z tej przyczyny średniowieczne wirydarze klasztorne, małe raje na ziemi, nazywane były przez św. Tomasza z Akwinu - paradisus terrestrum i tworzyły sui generis kopię Raju, do czego przyczyniała się ich odpowiednia, przesycona symboliką kompozycja.

Nie darmo Izydor z Sewilli (560-636) w swoich Etymologiach pisał: „Raj jest to miejsce [...] którego nazwa tłumaczona z greckiego na łacinę dała hortus. Poza tym w hebrajskim zwany jest Edenem, co w naszym języku znaczy rozkosz. Połączenie tych dwóch wyrazów daje hortus deliciarum" ${ }^{13}$.

11 J. Huizing, Jesień średniowiecza, Warszawa 1974, s. 237.

12 Z. Danielewicz, Niebo. Historia przyszłości, Warszawa 2005, s. 89.

13 Izydor z Sewilli, Etymologia, http://www.isidorus.net/show/isidorus,7 [12 I 2016]. 
Jednakże mimo nawiązań do ogrodu w Edenie, widać między nimi zasadniczą różnicę. Ogród biblijny, chociaż dla ludzi obecnie niedostępny, był otwarty, co znakomicie wyraził w swym aforyzmie pt. „Do raju przebojem” Adam Mickiewicz: „Do raju drzwi otwarte: ale rzadki zdoła/ Przebić się przez ogniste miecze archanioła.” Natomiast wirydarz średniowieczny był ogrodem zamkniętym, otoczonym murami - to był hortus conclusus, chociaż raczej winno się go nazywać ogrodem kontemplacyjnym (hortus contemplationis).

Mury wirydarzy stanowiły przeszkodę fizyczną, ale miały też swoją wymowę symboliczną, mistyczną. Wyznaczały wyraźnie granicę między światem zewnętrznym, pełnym grzechu i nieładu (profanum), a światem objętym murami klasztoru z panującym wewnątrz porządkiem (sacrum). Mury wznoszono z różnych materiałów, ale symbolicznie nawiązywały do opisów ścian Niebiańskiej Jerozolimy. Można nawet znaleźć opinię, że wyobrażają wprost osobę Chrystusa. Alan z Lille (zm. 1203) pisał: „Chrystus zwany jest murem [...] unicestwia bowiem najazd złych duchów pragnących dosięgnąć naszych serc".

Krużganki otaczające wirydarz, podobnie jak mury, także stanowiły jego rzeczywistą, fizyczną granicę. Ich kolumny z ozdobnymi kapitelami upodabniały się do drzew i tworzyły kształt sklepienia, tworząc coś w rodzaju rajskich alejek.

Do ogrodu potrzebny był jednak dostęp. Chociaż w Księdze Rodzaju nie podano liczby bram prowadzących do Raju, to jednak można przypuszczać, że była przynajmniej jedna. Mimo to podejmowano próby określenia liczby rajskich wrót. Np. w mitologii hebrajskiej podawano, że było ich siedem, z których jedna miała wychodzić na jaskinię w Hebronie, gdzie był pogrzebany Adam, zaś w Apokalipsie - dwanaście!! Brama także miała znaczenie symboliczne, np. jako przeciwieństwo bram piekielnych, bowiem wiodła do krainy szczęśliwości. Pamiętamy też słowa Chrystusa: „Ja jestem bramą. Jeżeli ktoś wejdzie przeze mnie będzie zbawiony” (J 10, 9). Znalazło to odbicie w architekturze kościelnej. Zachodnim fasadom 
kościołów nadawano nazwę porta coeli (brama Nieba) lub porta paradisi (brama Raju) ${ }^{14}$.

\section{Kształt wirydarza i jego symbolika}

Przestrzeń wirydarza, wytyczona i ogrodzona, nazwana i uporządkowana, a więc w jakiś sposób „oswojona”, stanowiła swoisty mikrokosmos i przybierała odpowiedni, symboliczny kształt.

Wirydarze były więc wyznaczane ściśle według zasad geometrii, nauki która w starożytności i w średniowieczu wraz z arytmetyką, astronomią i muzyką tworzyła tzw. quadrivium, co oznaczało „poczwórną ścieżkę" do mądrości.

Geometria była bardzo cenioną dziedziną nauk. Tak oto wychwala jej zalety Klemens Aleksandryjski, w dziele Kobierce: „Ta nauka przygotowuje duszę w najwyższym stopniu do prawidłowego wyciągania wniosków, uzdalnia do rozpoznawania prawdy i do wykazywania fałszu..." Gerbert z Aurillac (ok. 950-1003), który rozpowszechnił w Europie zapis cyframi arabskimi, pisał, że początkowo geometria została wynaleziona dla celów praktycznych, aby można było dokonać pomiarów ziemi, o czym świadczy jej nazwa (geo-metria) ${ }^{15}$. A czy o „geometrii” nie mówi też Księga Mądrości? Zgodnie z jednym ze średniowiecznych określeń Boga, Deus artifex (twórca, stworzyciel), podczas stwarzania świata posługiwał się zasadami matematyki i geometrii: "Aleś ty wszystko urządził według miary i liczby, i wagi” (Mdr 11, 20).

Geometria uważana była za jedną z najtrudniejszych nauk, dostępnych tylko dla światłych umysłów. Przypisywano ją Bogu - Umysłowi Umysłów, Wielkiemu Architektowi świata, określanemu nie tylko jak wspomniano - mianem Deus artifex, ale także Deus Geometra.

14 M. Krenz, Średniowieczna symbolika wirydarzy klasztornych..., s. 49-53.

15 A. Siemieniewski, Ścieżka nauki do Boga. Nauki przyrodnicze i duchowość w starożytności $i$ w średniowieczu, Warszawa 2009, s. 43, 258. 
Boecjusz (480-524) w dziele „Liber de geometria” podał taką oto definicję: „Geometria jest dyscypliną zajmującą się wielkością statyczną i opisaniem form na płaszczyźnie filozoficznej, przez którą można wyjaśnić jakiekolwiek terminy, jest także widzialnym dowodem filozofów, co w języku łacińskim określa się jako pomiar ziemi”"16. Według Kasjodora (ok. 490-ok. 583) rzymskiego pisarza chrześcijańskiego i historyka, autora dzieła „De geometria”: „geometria jest kontemplatywnym opisem figur, także widzialnym dowodem filozofów. [...] Jowisz w swoich dziełach okazał się geometrą"17.

Ponieważ geometria miała być atrybutem samego Boga, przypisywano jej funkcje nie tylko praktyczne, ale także mistyczne. Alan z Lille wyobraża sobie tę naukę, w postaci mądrej dziewicy, a ta: „pręt dzierży, którym świat cały obiega,/ Którym ziemi obszary odmierza, morze zamyka/ Granicami pewnymi, którym niebo wyniosłe okala”.

Tak więc figury geometryczne miały swoje znaczenie symboliczne, były nasycone znaczeniem. Ich symbolika to sposób odczytania świata Boskich idei, pomagająca szukania relacji Bóg - stworzenie i pozwalająca zrozumieć harmonię świata. Dlatego nie było obojętne jaki kształt powinno się nadać ogrodowi klasztornemu, namiastce Raju.

Do jak najlepszego odzwierciedlenia rajskiej szczęśliwości nadawały się szczególnie dwie figury: kwadrat i koło, a także, będące ich geometrycznymi modyfikacjami - pięciokąt i ośmiokąt.

Platon uznał kwadrat za figurę uosabiającą absolutne piękno, św. Augustyn za symbol sprawiedliwości (ze względu na równość wszystkich boków), zaś Beda Czcigodny (zm. 735) dodawał, że jest symbolem stabilności. Figura ta była uważana za symbol świata (cztery strony, cztery żywioły), a więc makrokosmosu oraz człowieka, którego np. św. Augustyn uważał za skondensowany świat czyli mikrokosmos,

16 Por: Boecjusz, Liber de geometria, https://books.google.pl/books$? \mathrm{id}=2$ T5s A A A A CA AJ $\&$ printsec $=$ frontcover $\& \mathrm{dq}=$ Liber $+\mathrm{de}+$ geometria $\& \mathrm{hl}=\mathrm{pl}$ \&sa=X\&ved=oahuKewj_X4Wru_fKAhvBGzoKHUGgDZMQ6AEIHjAA\#V=onepage\&q=Liber\%2ode\%2ogeometria\&f=false, (21 I 2016).

17 S. Kobielus, Człowiek i ogród rajski..., s. 23. 
a wyjaśnienie tego twierdzenia zawarł w „Objaśnieniach psalmów”, pisząc m.in.: „Sam Adam [będący reprezentantem wszystkich ludzi] [...] oznacza w języku greckim okrąg ziemi. Są bowiem cztery litery A, D, A, M. (...) cztery strony świata na początku mają te litery [które] tworzą imię Adam"18. Figura ta charakteryzuje się jednością i harmonią proporcji, toteż może być symbolem spokoju, odzwierciedlającego pierwotny rajski pokój i bezgrzeszność.

Koło było uważane za formę doskonałą, atrybut samego Boga, „Pana Koła”, który taki właśnie kształt miał nadać stworzonemu przez siebie światu. W ilustracjach niektórych ksiąg średniowiecznych, jak np. w „Liber Floridus” (z xiı w.), z opactwa św. Bawona w Gandawie. Na rycinie ukazano Raj otoczony kolistym murem $z$ bramami i wieżami, z drzewem życia pośrodku oraz inskrypcją "Paradysus”. Podobnie kolisty jest „Mistyczny raj ziemski”, przedstawiony na freskach Świętych Schodów (Scala Santa) w Rzymie, pędzla Giovanniego Guerry (xvi w.). Wspomniany Platon, $\mathrm{w}$ „Timaiosie” napisał, że „wytoczył bóg świat na okrągło... To kształt najdoskonalszy ze wszystkich.” Arystoteles był zdania, że koło jest kształtem doskonałym, najpiękniejszym, bo ani linia prosta, ani nieskończona nie ma jego doskonałości. Cyceron w „De natura deorum” pytał raczej retorycznie: „Czy jest coś piękniejszego od jedynego kształtu, który obejmuje zamknięte w sobie wszystkie inne kształty...”. Koło było też obrazem nieba, a nawet samego Boga, jak dowodzili m.in. św. Hildegarda z Bingen oraz moralista Piotr Berchoriusz (zm. 1362), który napisał: „Nie ma bowiem figura ta ani początku, ani końca. Takim z pewnością jest Bóg”. Godne uwagi są też poglądy na temat koła (kręgu) ludzi z innej, bliższej nam epoki i z zupełnie innych terenów, mianowicie Indian z plemienia Siuksów Oglala, mieszkańców Ameryki Północnej. Jeden z proroków tego plemienia, Czarny Łoś (1863-1950), powiedział niegdyś: „Wszystko co czyni Indianin, czyni w kręgu. Dzieje się tak, ponieważ moc wszechświata

18 M. Krenz, Średniowieczna symbolika wirydarzy klasztornych.., s. 30-31; J. Hani, Symbolika świątyni chrześcijańskiej, Kraków 1994, s. 16. 
zawsze działa w kręgu, a każda rzecz zmierza do okrągłości. (...) Niebo jest okrągłe (...) Podobnie wiatr, ten w całej swojej potędze tworzy wir. (...) Słońce wstaje i zachodzi, kreśląc krąg. Księżyc czyni to samo (...) Życie człowieka to krąg..."19.

Budowano „rajskie ogrody” także, choć rzadziej, na planie pięcioboku. Odwoływano się wtedy do magicznej siły tej formy, która symbolizowała panowanie człowieka nad złymi mocami, a więc była wyrazem potęgi człowieka i jego władzy nad poddaną mu naturą. Ponadto pięciobok był symbolem Chrystusa ( 5 ran zadanych podczas ukrzyżowania), a ponieważ w wielu kulturach liczba pięć symbolizowała miłość, w chrześcijaństwie przypisywano ją Duchowi Świętemu. Wreszcie liczba osiem, zawarta w ośmioboku, uważana za liczbę zbawienia i Nowego Testamentu (sam Chrystus był nazywany duchową Ósemką) była w średniowieczu symbolem doskonałości, nowego życia, jedności, wieczności, Ducha Świętego, wreszcie Raju² ${ }^{20}$.

\section{Układ i roślinne komponenty wirydarza}

Średniowieczne wirydarze budowano zatem przeważnie ad quadratum - na planie kwadratu. Cystersi np. twierdzili, że wirydarz założony na planie kwadratu przypomina jednocześnie o czterech rzekach w raju lub o czterech ewangelistach. Kwadratowy wirydarz symbolizował cztery cnoty kardynalne: roztropność, wstrzemięźliwość, sprawiedliwość i męstwo. Ponadto sama Niebiańska Jerozolima, jak pisze św. Jan, zbudowana była na planie czworoboku „A miasto układa się w czworobok... długość, szerokość i wysokość jego są równe” (Ap 21, 16).

19 C. Payment, Perły mądrości Indian, Warszawa 2011, s. 72-73.

20 W. Tatarkiewicz, O doskonałości (wybrane eseje), Daimonion, Lublin, 1991, s. 51; L. Impelluso, Ogrody i labirynty. Leksykon - historia, sztuka, ikonografia, Warszawa 2009, s. 339; S. Kobielus, Człowiek i ogród rajski..., s. 41, 49-50. 
Te ziemskie rajskie ogrody miały układ oparty na podziale na 4 części, wyznaczone przez 2 główne osie, które krzyżowały się pod kątem prostym co oczywiście symbolizowało krzyż. Centralnym elementem wirydarzy były: drzewo czyli drzewo krzyża, rzadziej ozdobny krzew albo studnia (źródło) ${ }^{21}$, a cztery krużganki ogrodu były niczym cztery strony świata.

Rajskie źródło miało dawać początek czterem wielkim rzekom: Piszon, Gichon, Chiddekel i Perat. Przypuszcza się, że dwie ostatnie to Eufrat i Tygrys. Według apokryficznej „Apokalipsy św. Pawła” pierwsza $\mathrm{z}$ czterech rzek płynęła miodem, mlekiem płynął Eufrat, winem - Tygrys, a oliwą - Giszon ${ }^{22}$. Symbolika rajskiego źródła była przedmiotem rozważań wielu autorów, które trudno tu szczegółowo przytaczać. Ograniczmy się do przywołania słów Chrystusa: „Jeśli ktoś jest spragniony, a wierzy we Mnie - niech przyjdzie do Mnie i pije! Jak rzekło Pismo: Strumienie wody żywej popłyną z jego wnętrza" (J 7, 37).

Dzięki obfitości wody, niezbędnej do uprawy ogrodowej, wirydarze mogły być miejscem bliższego współżycia ludzi z roślinami, zwłaszcza ozdobnymi i wonnymi. Harmonijna organizacja przestrzeni oraz dobór gatunków miały dostarczyć pozytywnych doznań estetycznych, pomagających wyzwalać odkrywanie duchowych wymiarów piękna i dobra przyswojonych przez zmysły ${ }^{23}$.

Jakże rozczulająco pisze o tym w $1540 \mathrm{r}$. Andrzej Trzycieski, tłumacz sławnego czternastowiecznego dzieła Pietra de Crescenzi (Krestentyna) Liber ruralium commodorum, w którym jeden rozdział poświęcony był zakładaniu ogrodów: „Wirydarze... są to ogródki małe, których

21 Oddajmy raz jeszcze głos Izydorowi z Sewilli: „Rosną w nim [raju] różnego rodzaju drzewa, zwłaszcza owocowe, a także drzewo życia [...]. Pośrodku bije źródło nawadniające cały teren" (Izydor z Sewilli, Etymologia, http://www. isidorus.net/show/isidorus,7 [12 I 2016]).

22 Apokryfy Nowego Testamentu, opr. D. Rops, F. Amiot, przeł. Z. Romanowiczowa, Londyn 1955, s. 233.

23 S. Jaromi, Idea ogrodu św. Franciszka ..., s. 83-94. 
ziółka abo drzewa (chocia też y oboie rostą wsadzone), aby zielonością swą ludziem czyniły lubosc i rozkosz..."24.

Urządzaniem ogrodów klasztornych interesował się sam cesarz Karol Wielki, który posiadał w pobliżu swego pałacu w Akwizgranie ogród kwietny założony zgodnie z orientalnymi wzorami Raju. W oparciu o projekt wirydarza opactwa Sankt Gallen, powstałego w 612 r. z inicjatywy św. Galla (Gawła), cesarz wydał edykt w 812 r. pod tytułem Capitulare de villis imperialibus, zawierający wykaz kwiatów, ziół i drzew, których uprawa była zalecana „wszystkim folwarkom i majątkom cesarskim", zwłaszcza klasztorom, gdzie uprawiano głównie rośliny lecznicze ${ }^{25}$. Jako ciekawostkę warto wspomnieć, że każdy bok krużganków tego wzorcowego wirydarza w St. Gallen miał długość ok. 30 metrów, a pośrodku rósł krzew, gatunek jałowca zwany sawiną ( $J u$ niperus savina), o właściwościach zarówno trujących, jak i leczniczych, którego gałęzi używano w niedzielę palmową do dekoracji kościołów. I tak, na planie ogrodu w St. Gallen zaznaczone są takie rośliny, które obecnie raczej nie są uznawane za zioła lecznicze, np.: lilia (lilium) również bób (fasiolum), cząber (sata regia), kozieradka (fenigrecum), rozmaryn (rosmarinum), ruta ogrodowa (ruta), irys (gladiolus), rzeżucha (sisimbra), kminek (cumino), lubczyk (lubestico) lub koper włoski (feniculum).

Próbowano zatem odtworzyć rajską roślinność, której Bóg nadał pierwszeństwo istnienia. Były to rośliny o niebiańskim - jak mówiono - rodowodzie, wspomniane w Biblii, często przeznaczone potem do dekoracji ołtarzy. Ich wysokość była nieznaczna, by nie przesłaniać zamykających przestrzeń wirydarza krużganków. Co ciekawe, są to przeważnie rośliny z naszej strefy, klimatu umiarkowanego.

Znalazły się więc wśród nich: jabłoń (Malus) i tuja (Thuja), które reprezentowały drzewo życia. Niewielka zielna roślinka, miodunka

24 G. Ciołek, Ogrody polskie. Przemiany treści i formy, Warszawa 1954, S. 14,16 .

25 S. Kobielus., Człowiek i ogród rajski..., s. 142. 
(Pulmonaria), u której na jednej łodydze wyrastają kwiaty zróżnicowane pod względem barwy (różowe i niebieskie), co sprawiło, że nazwano ją „Adam i Ewa”. Bluszcz (Hedera), o dwojakim kształcie liści, zależnym od wieku danego osobnika, nazywany został opisowo „tam, gdzie przechadzał się Bóg”, a żmijowiec (Echium), efektownie wyglądająca roślina o szorstkich łodygach i z rozdwojonymi końcówkami pręcika przywodził na myśl język węża-Szatana. Kolczasty oset (Carduus) miał wyobrażać Ewę i życie poza Rajem, zgodnie z zapowiedzią daną Adamowi („przeklęta niech będzie ziemia $z$ twego powodu ... cierń i oset będzie ci ona rodziła" - $\mathrm{Rdz} 3,17-19)$. Natomiast piękny tulipan (Tulipa) jest symbolem kobiety w ogóle, ale reprezentować ma nie tylko Ewę, ale też Marię, jako nową Ewę. Dość zaskakujące jest kojarzenie dziewanny (Verbascum) z „adamową bielizną”, służącą naszemu praojcu do przykrycia nagości po popełnieniu grzechu, zaś jukka (Yucca) z kolczasto zakończonymi liśćmi świetnie zastępowała igłę przy zszywaniu podartej odzieży. Wreszcie kwiatem pociechy dla Adama i Ewy był biały, uroczy i delikatny wiosenny kwiatuszek, przebiśnieg (Galanthus), który zakwitł po pierwszej zimie spędzonej przez nich na wygnaniu ${ }^{26}$.

\section{Nadzieja odzyskania raju}

Św. Bernard z Clairvaux (1090-1153) 27 $^{27}$ powiadał: „Zaprawdę, wirydarz jest rajem, obszarem chronionym przez szaniec dyscypliny, w którym mieści się mnogość cennych skarbów”28. To tutaj pielęgnowano pamięć raju przeszłego i nadzieję - przyszłego!

Bowiem - nadzieja powrotu do Raju pozostała w umysłach, a co najważniejsze w sercach ludzi! W Raju, po popełnieniu grzechu

26 M. Krenz, Średniowieczna symbolika wirydarzy klasztornych..., s. 59-60.

27 Cysters z klasztoru w Clairvaux, teolog, pisarz, filozof, kaznodzieja, kanonizowany w 1174 r. przez Aleksandra III, doktor kościoła (1830).

28 J. Delumeau, Historia raju..., s. 116. 
pierworodnego przez prarodziców, Bóg przeklął tylko węża: „...bądź przeklęty wśród wszystkich zwierząt domowych i polnych". Natomiast ludzie zostali wprawdzie ukarani, ale nie obłożeni klątwą. Co więcej, nieprzyjaźń wprowadzona przez Boga pomiędzy niewiastę i węża jest, w Protoewangelii ${ }^{29}$, zapowiedzią ostatecznej klęski węża, symbolizującego zło. Człowiek ma szansę osiągnąć zwycięstwo za cenę wielu trudów, za cenę przejścia przez śmierć, a przede wszystkim dzięki odkupieniu zapowiedzianemu w pierwszej dobrej nowinie! $!^{30}$

Dlatego poszukiwano raju na ziemi od bardzo, bardzo dawna. Lokowano go na wschodzie, szczególnie za czasów imperium rzymskiego, po tryumfie chrześcijaństwa lub - przeciwnie - na zachodzie, według starożytnej tradycji greckiej, mitologii celtyckiej, chińskiej i religii buddyjskiej, a np. mieszkańcy Indii szukali raju na północy. Warto też pamiętać, że istniał pogląd o położeniu raju w środku świata (to tzw. pępek świata czyli umbilicus mundi).

W Starym Testamencie Raj wiązany z ziemią i z czasem posiadał wymiar materialny, co oznaczało możliwość jego utraty, podczas gdy w Nowym Testamencie idea Raju została przeniesiona w obszar nadprzyrodzony, eschatologicznej nieutracalności ${ }^{31}$.

Poszukiwanie raju na ziemi trwa do dzisiaj. Czy są szanse na jego odnalezienie? Trzeba mocno wierzyć, że tak! Oto dwie, przeciwstawne opinie, dotyczące możliwości i sensu poszukiwania ziemskiego raju.

Thor Heyerdahl (budowniczy tratw Kon-Tiki i Ra, zm. 2002), planował jako młody człowiek ucieczkę od ograniczeń i sztuczności nowoczesnego społeczeństwa. Przez rok mieszkał z żoną na „nieskażonej” tropikalnej wyspie. Przeżył rozczarowanie i po powrocie do Norwegii napisał: „Nie ma już raju na ziemi. Znam ludzi żyjących w wielkich miastach, którzy są o wiele bardziej szczęśliwi niż większość tych, którzy

29 Wprowadzam nieprzyjaźń między ciebie a niewiastę, pomiędzy potomstwo twoje a potomstwo jej; ono zmiażdży ci głowę, a ty zmiażdżysz mu piętę $(\operatorname{Rdz} 3,14 \mathrm{n})$.

30 por. T. Jelonek, O raju i złotym wieku..., s. 36-41.

31 S. Kobielus, Człowiek i ogród rajski..., s. 187. 
zamieszkują południowy Pacyfik. Wiemy już teraz, że szczęście pochodzi z wnętrza [...] Człowiek może znaleźć raj we własnym umyśle i w sposobie życia, w umiejętności odkrycia prawdziwych wartości życiowych, które są czymś innym niż posiadanie i bogactwo, władza i zaszczyty" ${ }^{32}$. Interesujące, że tysiąc lat wcześniej (Ix w.), za rajem duchowym, gdzie uprawą Bożą jest ludzka natura („Vera enim plantatio Dei est natura ipsa...") opowiadał się Szkot Eriugena, nie wiążąc go z żadnym konkretnym miejscem (spiritualem et illocalem) ${ }^{33}$.

Inaczej twierdził Thomas Merton, czyli ojciec Ludwik, trapista, pisarz, poeta (zm. 1968): „Raj jest wszędzie wokół nas, a my tego nie pojmujemy".

Natomiast matka Herrada z Landsbergu (zm. 1195), przeorysza klasztoru św. Odylii w Alzacji, tak określa znaczenie słów „ziemski raj”: „Oznaczają one kolejno lub równocześnie (...) życie klasztorne, wirydarz, Kościół nawadniany przez cztery rzeki Ewangelii, a wreszcie Jeruzalem niebieską"34.

A przecież naszą tęsknotą, odziedziczoną po Adamie i Ewie, głównym celem naszego życia ziemskiego jest wejście do Niebieskiej Jerozolimy, do Raju, czyli tam, gdzie "przechadzał się Bóg”. Bowiem, „rajski ogród to archetypiczny ogród wieczności, miejsce początku i końca czasów, od zawsze uważane za symbol szczęścia ludzkiego" ${ }^{35}$, niezależnie od tego czy Raj pojmujemy metaforycznie, dosłownie czy mistycznie.

32 R. J. Berry, Bóg i biolog. Wiara a nauki przyrodnicze, Kraków 2005, s. 81.

33 S. Kobielus, Człowiek i ogród rajski..., s. 128.

34 Herrada of Hottenbourg (Landsberg), Hortus deliciarum, t. I, cyt. za M. Krenz, Średniowieczna symbolika wirydarzy klasztornych..., s. 26.

35 L. Impelluso, Ogrody i labirynty..., s. 297; M. Krenz, Średniowieczna symbolika wirydarzy klasztornych..., s. 54. 


\section{Bibliografia}

Apokryfy Nowego Testamentu, opr. D. Rops, F. Amiot, przeł. Z. Romanowiczowa, Londyn 1955.

Berry R. J., Bóg i biolog. Wiara a nauki przyrodnicze, Kraków 2005.

Ciołek G., Ogrody polskie. Przemiany treści i formy, Warszawa 1954.

Danielewicz D., Niebo. Historia przyszłości, Warszawa 2005.

Delumeau J., Historia raju. Ogród rozkoszy, Warszawa 1996.

Hani J., Symbolika świątyni chrześcijańskiej, Kraków 1994.

Hobhouse P., Historia ogrodów, Warszawa 2005.

Impelluso L., Ogrody i labirynty. Leksykon - historia, sztuka, ikonografia, Warszawa 2009.

Jaromi S., Idea ogrodu św. Franciszka jako przykład chrześcijańskiej troski o bioróżnorodność, [w:] Ogród Pana. XVIII Międzynarodowe Seminarium Sacrum i Przyroda, red. J. Brusiło, Kraków, 2010.

Jelonek T., O raju i złotym wieku, Kraków 2010.

Kobielus S., Człowiek i ogród rajski w kulturze religijnej średniowiecza, Warszawa, 1997.

Kopaliński W., Słownik symboli, Warszawa 2006.

Krenz M., Średniowieczna symbolika wirydarzy klasztornych, Kraków 2005.

Leksykon symboli - Herder, przeł. J. Prokopiuk, Warszawa 2009.

Modlitwy Hildegardy $z$ Bingen, oprac. W. Storch, tłum. K. Wiwer, Kraków 2008.

Payment C., Perly mądrości Indian, Warszawa 2011.

Pismo Święte Starego i Nowego Testamentu. Biblia Tysiaclecia, Wyd. IV, Poznań 1991.

Siemieniewski A., Ścieżką nauki do Boga. Nauki przyrodnicze i duchowość w starożytności i w średniowieczu, Warszawa 2009.

Słowacki J., Dzieła t. I: Liryki i inne wiersze, red. J. Krzyżanowskiego, wyd. III, Łódź 1959.

Symbole i alegorie. Leksykon - historia, sztuka, ikonografia, Warszawa 2011. 
Tatarkiewicz W., O doskonałości (wybrane eseje), Daimonion, Lublin, 1991.

Zemanek B., Ogród - raj odzyskany czy substytut natury [w:] Ogród Pana. XVIII Międzynarodowe Seminarium Sacrum i Przyroda, red. J. Brusiło, Kraków 2010. 